\title{
Effect of saline irrigation water on the leachability of salts, growth and chemical composition of wheat (Triticum aestivum L.) in saline-sodic soil supplemented with phosphorus and potassium
}

\author{
Z. Hussain', R. A. Khattak 2 , M. $\operatorname{Irshad}^{3 *}$, Q. Mahmood ${ }^{3}$, P. $\mathrm{An}^{4}$
}

${ }^{1}$ Department of Development Studies, COMSATS Institute of Information Technology, Abbottabad, Pakistan. ${ }^{2}$ CECOS University of Information Technology and Emerging Sciences, Hayatabad Peshawar, Khyber Pakhtunkhwa, Pakistan. ${ }^{3}$ Department of Environmental Sciences, COMSATS Institute of Information Technology, Abbottabad, Pakistan *Corresponding author: mirshad@ciit.net.pk. ${ }^{4}$ Arid Land Research Center, Tottori University, Hamasaka 1390, Tottori, Japan.

\begin{abstract}
Salinity-fertility interaction has not been properly explored especially in saline-sodic soils. Therefore, the current study investigated the response of wheat (Triticum aestivum L.) to saline irrigation water in salinesodic soil supplemented with potassium $(\mathrm{K})$ and phosphorus $(\mathrm{P})$. Wheat was grown in pots filled with salinesodic soil which were irrigated either with normal or saline water. Potassium and P fertilizers were applied at two levels. Results indicated that growth of wheat plants was impaired by saline irrigation resulting in a decreased grain and dry matter yield. The $\mathrm{P}$ application had significant effect on the dry matter yield and other yield components. Potassium application significantly increased dry matter yield and root mass. Wheat yield increased by 14 and $7 \%$ with the application of $150 \mathrm{~kg} \mathrm{~K}_{2} \mathrm{O} \mathrm{ha}^{-1}$ and $120 \mathrm{~kg} \mathrm{P}_{2} \mathrm{O}_{5}$ ha $^{-1}$ over the control soil under saline irrigation. The higher yield was obtained with combined $\mathrm{P}$ and $\mathrm{K}$ treatment under non-saline irrigation. The P addition significantly affected shoot and root $[\mathrm{P}]$ and $[\mathrm{Na}],[\mathrm{K}]$ and $[\mathrm{Mg}]$ in the shoot tissue while the $\mathrm{K}: \mathrm{Na}$ ratio produced non-significant effects under both irrigation waters. The addition of $\mathrm{K}$ significantly affected [Na], [K] and K:Na ratio in shoot. All other root parameters were significantly affected by the K addition. The $\mathrm{Ca}$ uptake by roots increased with saline irrigation. The $\mathrm{P}$ addition increased $[\mathrm{P}]$ in plant tissue. The Na uptake by root and shoot tissues was depressed with the addition of $\mathrm{P}$ and $\mathrm{K}$ fertilizers. The higher $\mathrm{K}$ uptake increased $\mathrm{K}: \mathrm{Na}$ ratio in both shoot and root tissues. The values of EC, SAR and [P], [Na], [Ca], [Mg], $[\mathrm{Cl}]$ and ratios of $\mathrm{Na}: \mathrm{K}, \mathrm{Ca}: \mathrm{P}, \mathrm{Cl}: \mathrm{P}$ and $\mathrm{SO}_{4}: \mathrm{P}$ in the soil leachates significantly increased with saline irrigation. The $\mathrm{P}$ addition had significant bearing on the soil $\mathrm{pH}, \mathrm{SAR},[\mathrm{P}],\left[\mathrm{SO}_{4}\right],\left[\mathrm{CO}_{3}\right]$ and $\left[\mathrm{HCO}_{3}\right]$ and $\mathrm{Ca}: \mathrm{P}, \mathrm{Cl}: \mathrm{P}$ and $\mathrm{SO}_{4}$ :P ratios in leachates. Saline irrigation significantly increased ECe, [Na], [K], [Ca], $[\mathrm{Mg}],[\mathrm{Cl}],\left[\mathrm{CO}_{3}\right]$, $\mathrm{SAR}$ and ratios of $\mathrm{Ca}: \mathrm{P}, \mathrm{Cl}: \mathrm{P}$ and $\mathrm{SO}_{4}: \mathrm{Cl}$ in saturated extracts of post-harvest soils. This study could suggest
\end{abstract}


that the addition of $\mathrm{P}$ and $\mathrm{K}$ under saline-sodic conditions may affect salts and nutrients dynamics of the soil and was useful for crop productivity.

Keywords: Saline irrigation water, wheat crop, nutrient concentration, leachability of salts, saline-sodic soil, fertilizers application

\section{Introduction}

Water scarcity has been observed for agriculture sector in the arid regions of the world. Such situation deems necessary to utilize marginal water quality for crop irrigation. The use of saline drainage waters in such environments shows promise for growing agricultural crops (Rhoades, 1987). Salinity is a severe problem which not only reduces the agricultural potential, but also creates serious effects on livelihood of farmers (Haider and Hossain, 2013). Salinity affects plants by depressing the external water potential along physical effects; additionally specific ions may have chemical effects. Growth is suppressed when salinity exceeds beyond a threshold (TH) value (Tanji, 1990). The higher is the electrical conductivity (EC), the less is the water available to plants, even though a field may appear wet. The amount of water transpired through a crop is directly related to its yield and irrigation water with higher EC reduces yield potential. Saline water resources are abundant than fresh water. Bringing these resources into sustainable productive use will offer opportunities to increase food security especially in developing countries. Several physical, chemical and biological soil management measures help to facilitate the safe use of saline water in crop production. The benefits anticipated from soil management practices to facilitate the safe use of saline water for irrigation will not be realized unless adequate supply of plant nutrients as fertilizers. Saline water irrigation containing phosphorus and potassium is essential for optimum crop productivity.
A general consensus about the excessive accumulation of soluble salts in the rhizosphere being a major reason for reduced osmotic potential of soil or nutrient solution and for unbalanced nutrition and specific ion phytotoxicity in salt affected soils. In plants, salinity can induce damages in proteins, lipids and nucleic acids, and alterations in photosynthesis and respiration which affect plant growth and development (Manai et al., 2014). The extent of growth inhibition caused by salinity on may be influenced by the nutritional status of plants. Constraints to crop productivity in salt affected soils may be overcome by leaching soluble salts from soil profiles by excess irrigation. This practice is no longer acceptable due to higher salinity in the streams and accumulation of salts in the deeper soil profile. The recycling of drainage water for irrigation is being considered as a best management practice.

Nutrient deficiency is yet another most prevalent constraint to agricultural production in saline or nonsaline soils. Sustained and profitable crops production of on salt-affected soils is feasible if appropriate on-farm management practices are used. Under low fertility status of soil, proper fertilizer applications can increase crop yields regardless of the soil salinity (Mass, 1990).

Therefore, investigating the fertilizer management to maximize crop production under existing salinity is of greater importance. 
Among the plant nutrients, potassium plays an important role to tolerate/mitigate ill effects of high salt contents in soils. It also helps to conserve water within plant itself. Its adequate levels in plants also enable roots to absorb/extract water from soils even under low moisture conditions. The $\mathrm{K}$ fertilizer application increased $\mathrm{K}$ movement from soil to root-surface and improved its availability to wheat roots (Ali et al., 1999). Phosphorus, like $\mathrm{K}$ and $\mathrm{N}$, is an important macronutrient involved in many essential functions in plant life especially in energy storage and transfer. The salinity $\mathrm{x} P$ interaction in plant nutrition is highly complex and sometimes confusing depending on the plant species, growth stage, salt types, degree of salinity and P content of growth media (Zhukovskaya, 1973).

Salinity and fertility interaction showed an improvement in the crop yield by addition of fertilizer to the soil irrigated with saline water (Muhammad and Khattak, 2009). The research studies on the response of wheat crop to the potassium and phosphate fertilizers in a saline-sodic soil irrigated with saline water is not well documented. Therefore, the objective of this study was to evaluate the influence of saline irrigation water on wheat crop in saline-sodic soil applied with $\mathrm{K}$ and $\mathrm{P}$ fertilizers.

\section{Materials and Methods}

An experiment was conducted at research farm of Agricultural University Peshawar-Pakistan. Wheat (Triticum aestivum L. cv. Inqilab-91) was grown in pots filled with saline-sodic soil. Each pot contained $6 \mathrm{~kg}$ soil collected from a saline-sodic field. Pots were irrigated either with normal tap water $\left(\mathrm{EC}_{\mathrm{tw}}=\right.$ $\left.0.6 \mathrm{dS} \mathrm{m}^{-1}\right)$ or saline water $\left(\mathrm{EC}_{\mathrm{sw}}=5.7 \mathrm{dS} \mathrm{m}^{-1}\right)$. Saline water was collected from a dug well of arid zone field. Two levels of $\mathrm{K}_{2} \mathrm{O}$ (0 and $150 \mathrm{~kg} \mathrm{ha}^{-1}$ denoted as $\mathrm{K}_{0}$ and $\mathrm{K}_{1}$ ) as $\mathrm{K}_{2} \mathrm{SO}_{4}$ and two levels of $\mathrm{P}_{2} \mathrm{O}_{5}(0$ and $120 \mathrm{~kg} \mathrm{ha}^{-1}$ denoted as $\mathrm{P} 0$ and $\mathrm{P} 1$ ) in the form of diammonium phosphate (DAP) were applied.
The experiment was laid out in 3-factorial randomized complete block design (RCBD) with four replications $\left[2 \mathrm{P}_{2} \mathrm{O}_{5} \times 2 \mathrm{~K}_{2} \mathrm{O} \times 2 \mathrm{EC}_{\mathrm{iw}} \times 4 \mathrm{R}\right]$. Each pot received 3.5L of water and total of six leachates were collected from each pot and analyzed for their chemical composition. The irrigation waters had two EC levels [saline and non-saline]. The values of $\mathrm{pH}, \mathrm{EC}$ and SAR were averaged for six leachates, while the concentrations of leached salts were also calculated. Post-harvest soil, plant and leachates samples were analyzed. Soil samples were air dried, gently crushed and sieved ( $2 \mathrm{~mm}$ ). Soil texture was determined by hydrometric method (Gee and Bauder, 1986). Similarly, plant shoot and roots were collected, washed with distilled water and oven-dried at $70^{\circ} \mathrm{C}$ for $48 \mathrm{~h}$ and ground in Wiley-Mill. The samples were analyzed for cations and anions following the methods described by Yoshida et al. (1976) and Benton et al. (1991). AB-DTPA-extractable P in the soil was determined colorimetrically (Soultanpour and Schwab, 1977). The $\mathrm{pH}$ values of soil suspension (1:5) and water samples were determined using $\mathrm{pH}$ meter (McLean, 1982; Thomas, 1996). Electrical conductivity (EC) was measured using a digital EC meter, Wiss. Techn. Werkstatten (WTW) D12 Weilheim. Potassium $(\mathrm{K})$ and sodium $(\mathrm{Na})$ in the soil extract, plant and water samples were analyzed by Perken-Elmer flame photometer (Richards, 1954). Calcium (Ca) and magnesium $(\mathrm{Mg})$ were determined in soil, plant and water samples by titration with EDTA. Carbonates and bicarbonates were determined by titration method. Chloride $(\mathrm{Cl})$ was determined by titration with silver nitrate (Richards, 1954). Sulfate content was determined using a turbidity method. Lime $\left(\mathrm{CaCO}_{3}\right)$ content of the soil was measured following Nelson and Sommers (1982). Sodium adsorption ratio (SAR) was determined using values of $\mathrm{Na}$ and $\mathrm{Ca}+\mathrm{Mg}$ concentrations $\left[\mathrm{mmol}(+) \mathrm{L}^{-1}\right]$ in soil saturation extracts and water samples. SAR of the soils and waters was calculated using the formula 1 . 


$$
\text { SAR }=\frac{[\mathrm{Na}]}{\sqrt{\frac{[\mathrm{Ca}+\mathrm{Mg}]}{2}}}
$$

The properties of soil and saline irrigation water are given in Table 1.
The data were analyzed using Microsoft Excel 2007 and the factorial analysis was done using MSTATC program. Means were separated using least significance test (LSD) test at probability of 0.05 .

Table 1. Chemical properties of saline-sodic soil and irrigation water

\begin{tabular}{l|l|l|l|l|l|l|l|l}
\hline Soil/water & $\mathrm{pH}_{(1: 5)}$ & $\mathrm{EC}$ & $\mathrm{P}$ & $\mathrm{Na}$ & $\mathrm{Ca}+\mathrm{Mg}$ & $\mathrm{K}$ & $\mathrm{SAR}$ & Texture \\
\hline \multirow{7}{*}{ Soil } & 8.24 & 6.22 & 2.1 & 53.8 & 13.5 & 0.27 & 20.7 & Silty clay loam \\
& & & & & & & & \\
Irrigation water & 8.1 & 5.70 & - & 36.7 & 23.0 & 0.08 & 10.8 & -- \\
\hline
\end{tabular}

Table 2. Yield and yield components of wheat as affected by the application of $\mathrm{K}$ and $\mathrm{P}$ under saline irrigation water

\begin{tabular}{|c|c|c|c|c|c|c|c|c|c|}
\hline $\mathrm{P}_{2} \mathrm{O}_{5}$ & $\mathrm{~K}_{2} \mathrm{O}$ & Grain yield & DM yield & Stem & Roots & Spike & Spike length & Plant height & Tillers plant ${ }^{-1}$ \\
\hline \multicolumn{2}{|c|}{$\mathrm{kg} \mathrm{ha}^{-1}$} & \multicolumn{2}{|c|}{ tha $^{-1}$} & \multicolumn{3}{|c|}{ g pot $^{-1}$} & \multicolumn{2}{|c|}{$\mathrm{cm}$} & No \\
\hline \multicolumn{10}{|c|}{ Non-saline irrigation water } \\
\hline \multirow[t]{2}{*}{0} & 0 & 2.6 & 17.5 & 8.7 & 3.8 & 9.3 & 10.0 & 59.7 & 2.1 \\
\hline & 150 & 2.8 & 18.9 & 9.4 & 4.6 & 9.9 & 10.3 & 63.6 & 2.3 \\
\hline \multirow[t]{2}{*}{120} & 0 & 2.9 & 21.1 & 11.6 & 4.8 & 10.9 & 10.8 & 61.7 & 2.7 \\
\hline & 150 & 3.0 & 20.7 & 10.5 & 5.1 & 11.1 & 10.9 & 64.0 & 2.6 \\
\hline \multicolumn{10}{|c|}{ Saline irrigation water } \\
\hline \multirow[t]{2}{*}{0} & 0 & 2.4 & 16.1 & 8.73 & 3.5 & 8.34 & 9.2 & 56.0 & 1.8 \\
\hline & 150 & 2.7 & 17.5 & 8.38 & 4.4 & 9.41 & 9.6 & 57.9 & 2.1 \\
\hline \multirow{2}{*}{120} & 0 & 2.6 & 17.9 & 9.33 & 4.5 & 9.25 & 10.0 & 59.3 & 2.1 \\
\hline & 150 & 2.7 & 18.5 & 9.71 & 4.9 & 9.27 & 9.9 & 60.0 & 2.3 \\
\hline \multicolumn{2}{|c|}{$\operatorname{LSD}(0.05)$} & 0.11 & 0.23 & 0.30 & 0.12 & 0.21 & 0.22 & 0.45 & 0.11 \\
\hline
\end{tabular}

\section{Results and Dicussion}

\subsection{Yield and yield components of wheat}

The summary of ANOVA suggested that EC of irrigation waters significantly $(\mathrm{p}<0.05)$ affected the grain and dry matter yield and all the other components except root mass (Table 2-3). The P application significantly affected dry matter yield, stem, root and spike weight, spike 1 ength and number of tillers plant ${ }^{-1}$.
The effects were non-significant $(\mathrm{p}>0.05)$ on grain yield and plant height. The $\mathrm{EC}_{\text {iw }} \times$ P interaction was non-significant $(p>0.05)$ for all the parameters except dry matter yield. Potassium application significantly $(\mathrm{p}<0.05)$ increased the dry matter yield and root biomass; while other parameters remained non-significant. The $\mathrm{EC}_{\mathrm{iw}}, \mathrm{K}, \mathrm{P}$ interactions produced non-significant ( $p>0.05$ ) effect on all the parameters except dry matter yield and stem mass which were significantly $(\mathrm{p}<0.05)$ affected by $\mathrm{Px} \mathrm{K}$ and $\mathrm{ECi}_{\mathrm{w}} \times \mathrm{P}$ $\mathrm{x} \mathrm{K}$ interactions, respectively (Tables 2-3). 
Table 3. Summary of analysis of variance (ANOVA) for yield and yield components of wheat as affected by the application of $\mathrm{K}$ and $\mathrm{P}$ with and without saline irrigation in saline-sodic soil

\begin{tabular}{lllllllll}
\hline Source of variation & Grain yield & $\begin{array}{c}\text { Dry matter } \\
\text { yield }\end{array}$ & Shoot & Roots & Spike & Spike length & Plant height & Tillers plant ${ }^{-1}$ \\
\hline ECiw & $9.81^{* *}$ & $52.3^{* * *}$ & $13.6^{* *}$ & $1.58^{\mathrm{NS}}$ & $51.5^{* * *}$ & $15.9^{* * *}$ & $12.9^{* *}$ & $6.21^{*}$ \\
P & $1.68^{\mathrm{NS}}$ & $52.5^{* * *}$ & $30.0^{* * *}$ & $15.6^{* * *}$ & $13.4^{* *}$ & $8.87^{* *}$ & $3.22^{\mathrm{NS}}$ & $6.73^{*}$ \\
ECiw x P & $1.47^{\mathrm{NS}}$ & $5.56^{*}$ & $3.53^{\mathrm{NS}}$ & $0.003^{\mathrm{NS}}$ & $2.84^{\mathrm{NS}}$ & $0.20^{\mathrm{NS}}$ & $0.49^{\mathrm{NS}}$ & $0.75^{\mathrm{NS}}$ \\
K & $3.97^{\mathrm{NS}}$ & $6.87^{*}$ & $0.14^{\mathrm{NS}}$ & $11.4^{* *}$ & $2.95^{\mathrm{NS}}$ & $0.99^{\mathrm{NS}}$ & $4.05^{\mathrm{NS}}$ & $1.62^{\mathrm{NS}}$ \\
ECiw x K & $0.003^{\mathrm{NS}}$ & $0.74^{\mathrm{NS}}$ & $0.18^{\mathrm{NS}}$ & $0.05^{\mathrm{NS}}$ & $1.17^{\mathrm{NS}}$ & $0.01^{\mathrm{NS}}$ & $0.72^{\mathrm{NS}}$ & $0.75^{\mathrm{NS}}$ \\
P x K & $2.50^{\mathrm{NS}}$ & $5.15^{*}$ & $0.99^{\mathrm{NS}}$ & $1.68^{\mathrm{NS}}$ & $1.48^{\mathrm{NS}}$ & $0.58^{\mathrm{NS}}$ & $0.38^{\mathrm{NS}}$ & $0.31^{\mathrm{NS}}$ \\
ECiw x P x K & $0.05^{\mathrm{NS}}$ & $0.66^{\mathrm{NS}}$ & $5.59^{*}$ & $0.02^{\mathrm{NS}}$ & $2.19^{\mathrm{NS}}$ & $0.21^{\mathrm{NS}}$ & $0.01^{\mathrm{NS}}$ & $0.21^{\mathrm{NS}}$ \\
\hline
\end{tabular}

$*, * *, * * *=$ Significant at $\mathrm{P}<0.05,0.01$ and 0.001 , respectively and NS $=$ Not-significant

The growth of the plants was adversely affected by saline irrigation $\left(\mathrm{EC}_{\mathrm{sw}}=5.7 \mathrm{dS} \mathrm{\textrm {m } ^ { - 1 }}\right)$ as compared to non-saline tap water $\left(\mathrm{EC}_{\mathrm{tw}}=0.6 \mathrm{dS} \mathrm{m} \mathrm{m}^{-1}\right)$ (Table $2-3)$. The grain and dry matter (DM) yield of wheat decreased to 2.4 and $16.1 \mathrm{t} \mathrm{ha}^{-1}$, respectively with saline irrigation when compared to 2.6 and $17.5 \mathrm{t}$ $\mathrm{ha}^{-1}$ in pots treated with non-saline irrigation water without $\mathrm{K}$ and $\mathrm{P}$ treatments (Table 2-3). The $\mathrm{K}$ addition significantly $(\mathrm{p}<0.05)$ increased DM yield with saline- and non-saline irrigation at $\mathrm{P}_{0}$ but at $\mathrm{P}_{1}$, the effect of $\mathrm{K}$ was non-significant. Higher grain yield $\left(2.97 \mathrm{t} \mathrm{ha}^{-1}\right)$ was obtained at $\mathrm{P}_{1}, \mathrm{~K}_{1}$ and $\mathrm{EC}_{\mathrm{tw}}$ and a lower yield of $2.4 \mathrm{t} \mathrm{ha}^{-1}$ was recorded at $\mathrm{P}_{0}$, $\mathrm{K}_{0}$ and $\mathrm{EC}_{\mathrm{sw}}$ (Table 2-3). Addition of P significantly $(\mathrm{p}<0.05)$ promoted the grain yield at $\mathrm{EC}_{\mathrm{tw}}$.

Respective wheat grain yield increase was 14 and 7\% at $150 \mathrm{~kg} \mathrm{~K}_{2} \mathrm{O} \mathrm{ha}^{-1}$ and $120 \mathrm{~kg} \mathrm{P}_{2} \mathrm{O}_{5} \mathrm{ha}^{-1}$ as compared to yield $\left(2.4 \mathrm{tha}^{-1}\right)$ without $\mathrm{K}$ and $\mathrm{P}$ with saline irrigation and increased grain yield by 21 and $22 \%$, respectively, with non-saline irrigation. The improvement in the grain yield due to the $\mathrm{K}$ and $\mathrm{P}$ additions could be attributed to the ameliorative effects of plant nutrition ( $\mathrm{K}$ and $\mathrm{P}$ ) on plant growth under salt stress conditions.
The highest yield was $2.97 \mathrm{t} \mathrm{ha}^{-1}$ employing combined $\mathrm{P}$ and $\mathrm{K}$ treatments under non-saline irrigation. The grain yield enhanced by $24 \%$ than control under saline irrigation (Table 2-3). Dry matter yield of wheat significantly $(\mathrm{p}<0.05)$ increased with the $\mathrm{P}(\mathrm{P}<0.001)$ and $\mathrm{K}$ $(\mathrm{P}<0.05)$ applications. $\mathrm{K}_{1}$ and $\mathrm{P}_{1}$ treatments increased DM yield by 8 and $21 \%$ under non-saline irrigation as compared to control. The combined $\mathrm{P}$ and $\mathrm{K}$ application promoted DM yield under both types of irrigations while the lower yield of $16.1 \mathrm{t} \mathrm{ha}^{-1}$ was recorded with saline irrigation after $\mathrm{P}$ and $\mathrm{K}$ treatment. A significant positive role of $\mathrm{P}$ in alleviating the adverse effects of salinity through increased nutrient uptake has been reported (Shibli et al., 2001). The enhancement of shoot yield due to $\mathrm{P}$ application proved to be useful in salinesodic soils (Cruz et al., 1990).

Saline irrigation water significantly $(\mathrm{P}<0.001)$ decreased the biomasses of stems $(\mathrm{P}<0.01)$ and wheat spikes (Tables 2-3). The stem, root and spike biomass increased with the separate $\mathrm{P}_{1}$ and $\mathrm{K}_{1}$ application. Combined $\mathrm{P}$ and $\mathrm{K}$ applications produced the higher biomass of stem, roots and spikes under non-saline water as compared to saline irrigation water (Tables 2-3). 
Saline irrigation significantly $(\mathrm{P}<0.001)$ deceased spike length, plant height $(\mathrm{P}<0.01)$ and tillers plant ${ }^{-1}(\mathrm{P}<0.05)$ as compared to control. The $\mathrm{P}$ and $\mathrm{K}$ addition improved almost all the parameters, when averaged across $(n=9)$ $\mathrm{K}, \mathrm{P}$ and $\mathrm{EC}_{\mathrm{iw}}$, respectively. The combined $\mathrm{P}_{1} \mathrm{~K}_{1}$ treatments with non-saline irrigation produced the higher spike length $(10.9 \mathrm{~cm})$ and plant height $(64.0 \mathrm{~cm})$, while these values decreased to 9.3 and $56 \mathrm{~cm}$, respectively with saline irrigation. A similar trend was observed regarding number of tillers plant ${ }^{-1}$ but the maximum numbers were obtained with P1 (Tables 2-3).

It has been previously reported that increased soil salinity resulted in reduction of plant growth, yield and, in severe case, total crop failure (Qadir et al., 2000). Rameeh (2012) reported significant interaction effects of salinity levels and genotypes for all the traits indicated that the variation trends of these traits among the genotypes were different at the salinity levels. In saline soils, water uptake by roots was limited because of higher osmotic potential which increased $\mathrm{Na}$ and $\mathrm{Cl}$ toxicity and thus plant production was affected in salt-affected soils (Flowers and Yeo, 1981). Also, the higher salinity caused P deficiency in wheat plants (Gibson, 1988). Evidence indicated that salinity may increase the P requirements of certain plants (Sharpley et al., 1992). The saline irrigation increased soil salinity which resulted in reduced wheat DM yield due to decreased growth of wheat leaves (Iqbal, 2003). The addition of $\mathrm{P}$ and $\mathrm{K}$ improved plant growth which could be associated with the improvement of plant nutrition and/ or with the mitigation of salt stress.

\subsection{Chemical composition of plant tissues}

The summary of ANOVA revealed that saline irrigation water significantly affected root tissue $[\mathrm{Ca}]$ and $\mathrm{K}: \mathrm{Na}$ ratio while all other ionic concentrations and $\mathrm{K}: \mathrm{Na}$ ratio in shoot tissue were non-significantly affected by saline irrigation water (Tables 4-5).
The $\mathrm{P}$ addition significantly affected shoot and root $[\mathrm{P}]$ and that of $[\mathrm{Na}],[\mathrm{K}]$ and $[\mathrm{Mg}]$ in shoot tissue while the ratio of $\mathrm{K}: \mathrm{Na}$ was non-significantly affected under both irrigation. The $\mathrm{EC}_{\mathrm{iw}} \times \mathrm{P}$ interaction had significant $(\mathrm{p}<0.05)$ effect on $[\mathrm{Na}]$ and $\mathrm{K}: \mathrm{Na}$ ratio in root tissues while $[\mathrm{P}],[\mathrm{Na}],[\mathrm{K}],[\mathrm{Ca}],[\mathrm{Mg}]$ and $\mathrm{K}: \mathrm{Na}$ ratios were not affected in shoot tissue. The $\mathrm{K}$ addition significantly affected $[\mathrm{Na}],[\mathrm{K}]$ and $\mathrm{K}: \mathrm{Na}$ ratio in shoot except $[\mathrm{P}]$ and $[\mathrm{Mg}]$. All other parameters were significantly affected by the addition of $\mathrm{K}$ in root. The $\mathrm{EC}_{\mathrm{iw}} \mathrm{x} \mathrm{K}$ interaction could not affect other parameters of shoot and root tissue. The P x K interactions significantly affected $[\mathrm{Ca}]$ and $[\mathrm{Mg}]$ in root tissue. Except $[\mathrm{Mg}]$ in shoot and $[\mathrm{Ca}]$ and $[\mathrm{Mg}]$ in root tissue, all other parameters were not affected by $\mathrm{EC}_{\mathrm{iw}} \times \mathrm{P}$ x K interaction (Table 4).

Shoot chemical analysis revealed that applied saline irrigation water affected ionic concentrations. The $\mathrm{Na}$ and $\mathrm{Mg}$ concentrations in the shoot increased with saline irrigation water whereas $\mathrm{K}$ concentration in plant shoot reduced in the unfertilized treatment. The Ca uptake by roots increased with saline irrigation irrespective of the $\mathrm{P}$ and $\mathrm{K}$ fertilization. The increasing $\mathrm{P}_{2} \mathrm{O}_{5}$ level from 0 to $120 \mathrm{~kg} \mathrm{ha}^{-1}$ with no $\mathrm{K}$, significantly increased [P] from 78.8 to 93.1 and 82.3 to 98.3 in shoot $(\mathrm{P}<0.05)$ and from 28.5 to 32.6 and 28.6 to $38.2 \mathrm{mmol}$ $\mathrm{kg}-1$ in root tissue $(\mathrm{P}<0.001)$ under non-saline and saline irrigation, respectively (Tables 4-5). $[\mathrm{P}]$ in shoot and root tissues was not affected by the addition of 150 $\mathrm{kg} \mathrm{K}_{2} \mathrm{O}$, however, an increasing trend in the combined treatment was observed with $120 \mathrm{~kg} \mathrm{P}_{2} \mathrm{O}_{5} \mathrm{ha}^{-1}$. When averaged across $\mathrm{EC}_{\mathrm{iw}}$ and $\mathrm{K}$ treatments $(\mathrm{n}=16)$, the $\mathrm{P}$ addition increased $[\mathrm{P}]$ in both shoot and root tissue (Table 4). Root hairs are specialized plant cells and are responsible for greatly increasing root surface area making them important for water and ion uptake, such as for P (Bates and Lynch, 2000). The enhancement of $\mathrm{P}$ absorption under saline irrigation suggested an improvement in the $\mathrm{P}$ nutrition for $\mathrm{P}$ addition. 
Table 4. Chemical composition of wheat shoot and root as affected by the application of $\mathrm{K}$ and $\mathrm{P}$ under saline irrigation water

\begin{tabular}{|c|c|c|c|c|c|c|c|c|c|c|c|c|c|}
\hline \multirow[b]{2}{*}{$\mathrm{P}_{2} \mathrm{O}_{5}$} & \multirow[b]{2}{*}{$\mathrm{K}_{2} \mathrm{O}$} & \multicolumn{6}{|c|}{ Shoot } & \multicolumn{6}{|c|}{ Root } \\
\hline & & $\mathrm{P}$ & $\mathrm{Na}$ & $\mathrm{K}$ & $\mathrm{Ca}$ & $\mathrm{Mg}$ & $\mathrm{K}: \mathrm{Na}$ & $\mathrm{P}$ & $\mathrm{Na}$ & $\mathrm{K}$ & $\mathrm{Ca}$ & $\mathrm{Mg}$ & $\mathrm{K}: \mathrm{Na}$ \\
\hline & & $\cdots$ & 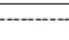 & $--\mathrm{mm}$ & $\cdots$ & -1 & & $\cdots$ & (n- & -mm & $-1 \ldots$ & (n) & \\
\hline & & & & & & & on-saline & irrigat & water & & & & \\
\hline \multirow[t]{2}{*}{0} & 0 & 78.8 & 372.7 & 393.0 & 39.0 & 25.6 & 1.06 & 28.5 & 254.0 & 131.1 & 448.9 & 98.3 & 0.53 \\
\hline & 150 & 76.7 & 349.6 & 468.7 & 18.3 & 32.1 & 1.35 & 29.3 & 224.9 & 177.6 & 331.0 & 82.4 & 0.79 \\
\hline \multirow[t]{3}{*}{120} & 0 & 93.1 & 347.5 & 388.1 & 25.5 & 41.4 & 1.12 & 32.6 & 312.3 & 150.3 & 403.2 & 90.4 & 0.49 \\
\hline & 150 & 88.2 & 330.0 & 433.1 & 00.6 & 37.3 & 1.33 & 32.9 & 259.7 & 180.6 & 260.7 & 71.9 & 0.71 \\
\hline & & \multicolumn{12}{|c|}{ Saline irrigation water } \\
\hline \multirow[t]{2}{*}{0} & 0 & 82.3 & 450.8 & 372.2 & 27.7 & 36.7 & 0.85 & 28.6 & 281.5 & 159.4 & 434.4 & 67.7 & 0.57 \\
\hline & 150 & 83.9 & 351.3 & 512.3 & 10.5 & 26.3 & 1.47 & 29.1 & 250.8 & 182.7 & 564.6 & 120.0 & 0.75 \\
\hline \multirow[t]{2}{*}{120} & 0 & 98.3 & 357.8 & 362.6 & 23.7 & 38.2 & 1.02 & 38.2 & 225.2 & 154.9 & 670.7 & 127.9 & 0.70 \\
\hline & 150 & 90.8 & 309.5 & 426.1 & 12.8 & 41.2 & 1.39 & 35.7 & 217.1 & 192.7 & 447.5 & 63.0 & 0.93 \\
\hline \multicolumn{2}{|c|}{$\operatorname{LSD}(0.05)$} & 1.23 & 6.45 & 6.56 & 0.12 & 1.45 & 0.10 & 0.26 & 6.56 & 3.45 & 6.78 & 4.55 & 0.07 \\
\hline
\end{tabular}

Table 5. Chemical composition of leachate of saline-sodic soil as affected by $\mathrm{P}$ and $\mathrm{K}$ under saline and non-saline irrigation

\begin{tabular}{|c|c|c|c|c|c|c|c|c|c|c|c|c|c|}
\hline $\mathrm{P}_{2} \mathrm{O}_{5}$ & $\mathrm{~K}_{2} \mathrm{O}$ & $\mathrm{EC}$ & $\mathrm{pH}$ & SAR & $P$ & $\mathrm{Na}$ & $\mathrm{K}$ & $\mathrm{Ca}$ & $\mathrm{Mg}$ & $\mathrm{Cl}$ & $\mathrm{SO}_{4}$ & $\mathrm{CO}_{3}$ & $\mathrm{HCO}_{3}$ \\
\hline \multicolumn{2}{|c|}{$\mathrm{kg} \mathrm{ha}^{-1}$} & $\mathrm{dS} \mathrm{m}^{-1}$ & & & $\mathrm{mg} \mathrm{L}^{-1}$ & $\cdots$ & 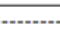 & 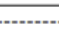 & $-\cdots-m m$ & $\mathrm{~L}^{-1} \ldots$ & $\cdots$ & (n)..... & (n...- \\
\hline \multicolumn{14}{|c|}{ Non-saline irrigation water } \\
\hline \multirow[t]{2}{*}{0} & 0 & 9.40 & 8.02 & 14.6 & 0.15 & 34.7 & 0.22 & 8.81 & 8.05 & 31.3 & 18.7 & 0.24 & 1.41 \\
\hline & 150 & 11.8 & 8.04 & 18.3 & 0.14 & 48.4 & 0.26 & 10.3 & 9.70 & 41.0 & 25.5 & 0.20 & 1.53 \\
\hline \multirow[t]{2}{*}{120} & 0 & 10.7 & 7.97 & 13.9 & 0.35 & 38.4 & 0.23 & 10.3 & 10.1 & 39.6 & 17.4 & 0.26 & 1.60 \\
\hline & 150 & 11.7 & 7.97 & 16.8 & 0.36 & 47.6 & 0.25 & 10.5 & 9.95 & 42.5 & 23.2 & 0.32 & 1.70 \\
\hline \multicolumn{14}{|c|}{ Saline irrigation water } \\
\hline \multirow[t]{2}{*}{0} & 0 & 12.2 & 8.05 & 16.6 & 0.13 & 43.7 & 0.24 & 10.4 & 10.5 & 41.6 & 21.7 & 0.21 & 1.25 \\
\hline & 150 & 12.9 & 7.97 & 20.5 & 0.11 & 54.9 & 0.28 & 11.1 & 10.5 & 49.9 & 25.0 & 0.22 & 1.49 \\
\hline \multirow[t]{2}{*}{120} & 0 & 11.7 & 7.97 & 16.4 & 0.31 & 42.0 & 0.24 & 10.8 & 10.9 & 45.1 & 16.8 & 0.30 & 1.52 \\
\hline & 150 & 13.4 & 7.99 & 20.1 & 0.31 & 52.0 & 0.28 & 11.1 & 10.8 & 48.7 & 23.2 & 0.31 & 1.56 \\
\hline \multicolumn{2}{|c|}{$\operatorname{LSD}(0.05)$} & 1.23 & 1.34 & 1.45 & 0.02 & 1.56 & 0.02 & 0.34 & 0.03 & 0.34 & 0.12 & 0.04 & 0.05 \\
\hline
\end{tabular}


The $[\mathrm{Na}]$ in shoot and root tissue was affected by the applied saline water (Table 4). The Na uptake by root tissue and its translocation to shoot tissue was significantly depressed with the addition of $\mathrm{P}$ and $\mathrm{K}$ fertilizers. The $\mathrm{K}$ and $\mathrm{P}$ addition tended to decrease $[\mathrm{Na}]$ in shoot with saline waters. The lower Na concentration measured in the wheat plants on the P addition as DAP could be as a result of lower $\mathrm{Na}$ uptake in response to $\mathrm{NH}_{4}$ uptake. The differences in $\mathrm{Na}$ concentration in plant tissues in response to $\mathrm{P}$ application under saline conditions might be related to its accompanying cation $\left(\mathrm{NH}_{4}\right)$. The higher [Na] of $450 \mathrm{mmol} \mathrm{kg}^{-1}$ shoot was noticed at $\mathrm{K}_{0}$ and $\mathrm{P}_{0}$ in saline treatments which substantially decreased with $\mathrm{K}$ and reaching to a lower value of $309 \mathrm{mmol} \mathrm{kg}^{-1}$ at $\mathrm{P}_{2} \mathrm{~K}_{2}$. Roots maintained lower [Na] than shoot and exhibited similarity between $\mathrm{P}$ and $\mathrm{K}$ effect on $[\mathrm{Na}]$ under saline irrigation.

The increasing $\mathrm{K}$ levels enhanced $(\mathrm{P}<0.001)[\mathrm{K}]$ in both root and shoot tissue (Table 4 ). The $\mathrm{K}$ concentration of 512 and $192 \mathrm{mmol} \mathrm{kg}^{-1}$ was recorded in shoot and root, respectively with $\mathrm{K} 1$ when irrigated with saline water. It was observed that the addition of $\mathrm{P}_{2} \mathrm{O}_{5}$ as DAP significantly $(\mathrm{P}<0.05)$ reduced $[\mathrm{K}]$, which may be due to the dilution effect associated with increases in yield as the total $\mathrm{K}$ accumulation increased with P (Jarrell and Baverly, 1981). A consistent decreases in leaf tissue $[\mathrm{Na}]$ and increases in $[\mathrm{K}]$ with addition of 50 and $100 \mathrm{~kg} \mathrm{~K} \mathrm{ha}^{-1}$ under saline conditions have been reported (Hussain et al., 2013).

The higher $\mathrm{K}$ uptake significantly $(\mathrm{P}<0.001)$ increased $\mathrm{K}: \mathrm{Na}$ ratio in both shoot and root tissue. The addition of $\mathrm{K}_{1}$ alone raised $\mathrm{K}: \mathrm{Na}$ ratios of the leaf tissues to 1.4 and 1.5 as compared to 1.0 and 0.9 in control under non-saline and saline irrigation, respectively (Table 4). A similar trend was observed in root tissues. When averaged across $\mathrm{EC}_{\mathrm{iw}}$ and $\mathrm{P}$, the higher values of $\mathrm{K}: \mathrm{Na}$ ratio were obtained with $\mathrm{K}_{1}$ treatment in both shoot and root tissue. The K:Na ratio in shoot was positively related to shoot $[\mathrm{K}]$. Data of yield, $[\mathrm{P}],[\mathrm{K}]$ and their total accumulation suggested that yield slightly increased with increasing P levels, [K] decreased while total $\mathrm{K}$ accumulation increased. Thus the observed changes in $[\mathrm{K}]$ could be associated with the classical dilution effect as reported by Jarrell and Beverly (1981). Total Na accumulation decreased hence the $\mathrm{K}: \mathrm{Na}$ in total biomass of wheat increased with increasing total $\mathrm{K}$ accumulation at $\mathrm{P}_{0}$ under both non-saline and saline irrigations.

The tolerance of wheat to salts was associated with the preferential accumulation of $\mathrm{K}$ against higher [Na] (Zaman et al., 2005) that might have depressed Na uptake. Addition of $\mathrm{K}$ alone or in combination with $\mathrm{P}$ in saline medium significantly increased $[\mathrm{K}]$ and decreased [Na] thus increasing $\mathrm{K}: \mathrm{Na}$ in wheat leaves (Shirazi et al., 2005). The enhanced $\mathrm{K}$ uptake could be associated with direct competition between $\mathrm{K}$ and $\mathrm{Na}$ at root plasmalemma; an effect of $\mathrm{K}$ on $\mathrm{Na}$ transport into xylem and/or $\mathrm{K}$ induced net $\mathrm{Na}$ extrusion from roots (Munns et al., 1983). Salt tolerance of Triticeae was associated with enhanced ability to discriminate between $\mathrm{Na}$ and $\mathrm{K}$ in the soil solution and to preferentially accumulate $\mathrm{K}$ and exclude $\mathrm{Na}$ (Ali et al., 2004). It was reported that the K:Na discrimination character enhances a process already operating in cereal roots and to a greater or lesser extent in the roots of all plants (Ashraf and Sarwar, 2002). The selective uptake of $\mathrm{K}$ over $\mathrm{Na}$ by roots and the effects of $\mathrm{K}$ on reduced $\mathrm{Na}$ translocation to shoot resulting an overall increase in $\mathrm{K}: \mathrm{Na}$ in the present study corroborated the importance of $\mathrm{K}$ in minimizing Na hazard and improving crop growth.

The concentrations and total $\mathrm{Ca}$ accumulation in shoot and root decreased non-significantly with increasing $\mathrm{K}$ levels at both $\mathrm{P}$ and waters levels (Table 4). The $[\mathrm{Mg}]$ significantly $(\mathrm{P}<0.001)$ increased in shoot tissue at $\mathrm{P} 1$ alone with non-saline irrigation. However, the treatments had no effect on $[\mathrm{Mg}]$ concentrations in root tissue. The $[\mathrm{Mg}]$ were found very low when compared with $[\mathrm{Ca}]$ in both shoot and root (Table 4). 
The overall [Ca] were higher in shoot and root tissue. The decrease [Ca] could be associated with P and especially $\mathrm{K}$ treatments in this study. This could be due to the interactions of $\mathrm{Na}, \mathrm{K}$ or $\mathrm{Ca}$ at the sites of uptake in roots (Gronwald et al., 1990). Lynch and Lauchli (1985) reported that $[\mathrm{Na}]$ in root medium might induce $\mathrm{Ca}$ deficiency in plants grown with lower $\mathrm{Ca}$. Since $\mathrm{Ca}$ plays a vital nutritional and physiological role in plant metabolism, $\mathrm{Na}$ induced $\mathrm{Ca}$ deficiencies have growth-distorting effects on developing leaves (Maas and Grieve, 1987). The presence of Ca might have mitigated the adverse effects of $\mathrm{Na}$ as suggested by the results of current study which also improved K:Na ratio in shoot and root (Minhas, 1996). Kinraide (1999) reported the interactions among $\mathrm{Ca}, \mathrm{Na}$ and $\mathrm{K}$ in saline medium and their multiple toxic and ameliorative effects on root and shoot of wheat and observed that higher $[\mathrm{Na}]$ in the rooting medium and the tissues were not toxic unless [Ca] was also deficient. Higher $[\mathrm{Na}]$ and lower $[\mathrm{Ca}]$ inhibited shoot growth of rice cultivars and triticale lines (Grieve and Fujiyama, 1987). In saline soils, $[\mathrm{Ca}]$ increase as the total salt concentration increases. The $\mathrm{Ca}$ accumulation by plants from the soil solution can decrease because of ionic competition for absorption sites and with processes of precipitation and solubilization in the soil solution. The Ca activity is decreased by increasing the ionic strength of the solution which substantially affects its uptake. These combined effects together in a complex soil-plant system eventually reduce plant growth and yield under saline or saline-sodic conditions.

The growth of shoot increased and the Ca disorder was alleviated and the $[\mathrm{Na}]$ was lowered. The findings of the present study involving the effects of $\mathrm{P}$ and $\mathrm{K}$ treatments and their interactions resulted in higher $[\mathrm{P}],[\mathrm{K}]$ and $[\mathrm{Ca}]$ and depressed uptake of $\mathrm{Na}$ by plant and this gave higher yields. This study suggested that the addition of $\mathrm{P}$ and $\mathrm{K}$ under saline conditions may be beneficial to crop growth due to high selectivity of roots for $\mathrm{K}$ over $\mathrm{Na}$ and its translocation to shoots thus minimizing the adverse effects of $\mathrm{Na}$ in plant growth.

\subsection{Chemical composition of soil leachate}

Electrical conductivity (EC), SAR and $[\mathrm{P}],[\mathrm{Na}],[\mathrm{Ca}]$, $[\mathrm{Mg}],[\mathrm{Cl}]$ and ratios of $\mathrm{Na}: \mathrm{K}, \mathrm{Ca}: \mathrm{P}, \mathrm{Cl}: \mathrm{P}$ and $\mathrm{SO}_{4}: \mathrm{P}$ in leachates significantly increased with saline irrigation while $\mathrm{pH}$ values and $[\mathrm{K}],\left[\mathrm{SO}_{4}\right],\left[\mathrm{CO}_{3}\right]$ and $\left[\mathrm{HCO}_{3}\right]$ did not change with saline irrigation waters. The addition of $\mathrm{P}$ to soils had significant effect on $\mathrm{pH}, \mathrm{SAR},[\mathrm{P}]$, $\left[\mathrm{SO}_{4}\right],\left[\mathrm{CO}_{3}\right]$ and $\left[\mathrm{HCO}_{3}\right]$ and $\mathrm{Ca}: \mathrm{P}, \mathrm{Cl}: \mathrm{P}$ and $\mathrm{SO}_{4}: \mathrm{P}$ ratios in leachates, while $\mathrm{EC},[\mathrm{Na}],[\mathrm{K}],[\mathrm{Ca}],[\mathrm{Mg}],[\mathrm{Cl}]$ and Na:K ratio were not affected with $\mathrm{P}$ levels. The $\mathrm{EC}_{\mathrm{iw}} \times \mathrm{P}$ interaction had no effect on all the ionic concentrations except ratios of $\mathrm{Ca}: \mathrm{P}, \mathrm{Cl}: \mathrm{P}$ and $\mathrm{SO}_{4}: \mathrm{P}$ (Table 5). The addition of $\mathrm{K}$ significantly affected values of $\mathrm{EC}, \mathrm{SAR}$ and $[\mathrm{Na}],[\mathrm{K}],[\mathrm{Cl}],\left[\mathrm{SO}_{4}\right]$ and $\left[\mathrm{HCO}_{3}\right]$ and $\mathrm{Ca}: \mathrm{P}, \mathrm{Cl}: \mathrm{P}$ and $\mathrm{SO}_{4}: \mathrm{P}$ ratios while other parameters remained unchanged.

A total of 32 pots receiving treatments $\left[2 \mathrm{EC}_{\mathrm{iw}} \times 2 \mathrm{P} \times\right.$ $2 \mathrm{~K} \times 4 \mathrm{R}]$ were arranged in open air and each pot received total irrigation water of $3.5 \mathrm{~L}$. The chemical analysis of leachates gave an insight to understand the complex soil-plant-leachate system under the $\mathrm{P}$ and $\mathrm{K}$ treatments and saline irrigation waters. Mean EC values of all leachates showed substantial leaching of salts with significant increase $\left(13.8 \mathrm{dS} \mathrm{m}^{-1}\right)$ by the addition of combined $120 \mathrm{~kg} \mathrm{P}_{2} \mathrm{O}_{5} \mathrm{ha}^{-1}$ and $150 \mathrm{~kg} \mathrm{~K}_{2} \mathrm{O}$ $\mathrm{ha}^{-1}$ with saline irrigation $\left(\mathrm{EC}_{\mathrm{sw}}=5.7 \mathrm{dS} \mathrm{m}^{-1}\right)$ as compared to $9.40 \mathrm{dS} \mathrm{m}^{-1}$ in control with non-saline irrigation (Table 5). Mean values showed that the leachates with saline irrigation had slightly higher EC than in those with non-saline irrigation. The high EC and SAR values of leachate (Table 5) due to applied treatments and irrigation were indicative of the reduction in soil salinity-sodicity as evident from $\mathrm{EC}_{\mathrm{e}}$ and $\mathrm{SAR}$ of postharvest soil. Significant reduction in soil $\mathrm{EC}_{\mathrm{e}}$ (Table 7) proved the effect of irrigation on leaching of salts. 
Table 6. Salts concentrations in leachates collected from saline-sodic soil after application of $\mathrm{P}$ and $\mathrm{K}$ under saline and non saline irrigation

\begin{tabular}{|c|c|c|c|c|c|c|c|c|c|}
\hline $\mathrm{P}_{2} \mathrm{O}_{5}$ & $\mathrm{~K}_{2} \mathrm{O}$ & Volume & $\mathrm{Na}: \mathrm{K}$ & $\mathrm{Na}: \mathrm{Ca}$ & $\mathrm{Ca}: \mathrm{K}$ & $\mathrm{Ca}: \mathrm{P}$ & $\mathrm{Cl}: \mathrm{P}$ & $\mathrm{SO}_{4}: \mathrm{P}$ & $\mathrm{Cl}: \mathrm{SO}_{4}$ \\
\hline 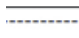 & -1......... & $\mathrm{mL}$ & & & & & & & \\
\hline \multicolumn{10}{|c|}{ Non-saline irrigation water } \\
\hline \multirow[t]{2}{*}{0} & 0 & 2481 & 158.7 & 3.93 & 40.5 & 60.3 & 213.0 & 127.5 & 1.67 \\
\hline & 150 & 2429 & 186.5 & 4.72 & 39.6 & 73.5 & 293.6 & 183.8 & 1.62 \\
\hline \multirow[t]{2}{*}{120} & 0 & 2344 & 171.0 & 3.74 & 45.8 & 29.9 & 115.4 & 50.9 & 2.30 \\
\hline & 150 & 2469 & 188.4 & 4.53 & 41.5 & 29.4 & 119.4 & 65.3 & 1.84 \\
\hline \multicolumn{10}{|c|}{ Saline irrigation water } \\
\hline \multirow[t]{2}{*}{0} & 0 & 2340 & 181.0 & 4.19 & 43.2 & 87.2 & 346.4 & 179.3 & 1.93 \\
\hline & 150 & 2586 & 198.9 & 4.94 & 40.2 & 99.1 & 444.9 & 221.5 & 2.01 \\
\hline \multirow[t]{2}{*}{120} & 0 & 2399 & 175.9 & 3.92 & 45.1 & 35.4 & 148.2 & 55.3 & 2.72 \\
\hline & 150 & 2475 & 189.5 & 4.70 & 40.4 & 36.9 & 162.7 & 77.2 & 2.10 \\
\hline \multicolumn{2}{|c|}{$\operatorname{LSD}(0.05)$} & 3.26 & 5.36 & 0.44 & 1.62 & 3.58 & 5.77 & 4.26 & 0.02 \\
\hline
\end{tabular}

Table 7. Chemical composition of post-harvest soil as affected by the application of $\mathrm{P}$ and $\mathrm{K}$ under saline irrigation water

\begin{tabular}{|c|c|c|c|c|c|c|c|c|c|c|c|c|c|}
\hline $\mathrm{P}_{2} \mathrm{O}_{5}$ & $\mathrm{~K}_{2} \mathrm{O}$ & $\mathrm{EC}_{\mathrm{e}}$ & $\mathrm{pH}_{(1: 5)}$ & $\begin{array}{l}\text { ABDTPA } \\
\mathrm{P}\end{array}$ & $\mathrm{Na}$ & $\mathrm{K}$ & $\mathrm{Ca}$ & $\mathrm{Mg}$ & $\mathrm{CO}_{3}$ & $\mathrm{HCO}_{3}$ & $\mathrm{Cl}$ & $\mathrm{SO}_{4}$ & SAR \\
\hline \multirow[t]{2}{*}{$\mathrm{kgha}^{-1}$} & & $\mathrm{dS} \mathrm{m}^{-1}$ & & $\mathrm{mg} \mathrm{kg}^{-1}$ & $\cdots$ & 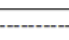 & $\cdots$ & $----m r$ & t) $\mathrm{L}^{-1}$ & -non & $\cdots$ & $\cdots$ & \\
\hline & \multicolumn{13}{|c|}{ Non-saline irrigation water } \\
\hline \multirow[t]{2}{*}{0} & 0 & 1.81 & 8.80 & 8.0 & 12.5 & 0.17 & 3.56 & 4.88 & 0.60 & 4.40 & 3.50 & 8.93 & 6.12 \\
\hline & 150 & 1.83 & 8.81 & 8.8 & 11.0 & 0.28 & 4.06 & 4.94 & 1.05 & 4.53 & 2.69 & 12.6 & 5.21 \\
\hline \multirow[t]{2}{*}{120} & 0 & 1.83 & 8.86 & 14.1 & 13.5 & 0.15 & 3.55 & 5.38 & 1.03 & 4.85 & 3.81 & 9.20 & 6.40 \\
\hline & 150 & 1.78 & 8.98 & 13.7 & 12.0 & 0.27 & 3.06 & 4.81 & 1.00 & 4.40 & 3.38 & 12.0 & 6.04 \\
\hline \multicolumn{14}{|c|}{ Saline irrigation water } \\
\hline \multirow[t]{2}{*}{0} & 0 & 2.70 & 8.82 & 10.1 & 17.4 & 0.28 & 5.00 & 7.38 & 0.93 & 4.18 & 11.0 & 10.9 & 7.00 \\
\hline & 150 & 2.48 & 8.78 & 10.1 & 14.2 & 0.34 & 4.06 & 6.63 & 0.78 & 4.00 & 9.45 & 12.2 & 6.13 \\
\hline \multirow[t]{2}{*}{120} & 0 & 2.60 & 8.89 & 13.7 & 17.2 & 0.26 & 5.19 & 6.31 & 0.78 & 4.35 & 10.2 & 8.75 & 7.17 \\
\hline & 150 & 2.63 & 8.81 & 13.3 & 13.1 & 0.35 & 4.88 & 7.51 & 0.55 & 4.20 & 10.7 & 11.8 & 5.26 \\
\hline \multicolumn{2}{|c|}{$\operatorname{LSD}(0.05)$} & 0.33 & 0.82 & 0.34 & 0.45 & 0.05 & 0.23 & 0.21 & 0.07 & 0.12 & 0.14 & 0.17 & 0.56 \\
\hline
\end{tabular}


However, saline irrigation contributed to higher EC values of leachates.

Efficiency of treatments for removing $\mathrm{Na}$ from soil was evaluated as mmol of total $\mathrm{Na} \mathrm{kg}^{-1}$ leached. Irrigation with saline water significantly increased $[\mathrm{Na}]$ in all leachates while $[\mathrm{K}]$ was not affected with saline irrigation water (Table 5-6). The addition of $\mathrm{K}$ significantly increased $[\mathrm{Na}], \mathrm{Na}: \mathrm{K}$ ratio and SAR of the leachates. The values showed that $[\mathrm{Na}]$ were significantly increased with $150 \mathrm{~kg} \mathrm{~K}_{2} \mathrm{O}$ ha $^{-1}$ alone (48 and $55 \mathrm{mmol}$ $\mathrm{kg}^{-1}$ ) or in combination with $120 \mathrm{~kg} \mathrm{P}_{2} \mathrm{O}_{5} \mathrm{ha}^{-1}$ (47 and $52 \mathrm{mmol} \mathrm{kg}^{-1}$ ) with non-saline or saline irrigation, respectively. However, [Na] were slightly higher with saline irrigation (Table 6-8). The $\mathrm{K}$ addition treatments played significant role in leaching of $\mathrm{Na}$ thus increasing $\mathrm{Na}: \mathrm{K}$ ratios in nearly all the leachates, especially to 198.9 at $\mathrm{K}_{1}$ as compared to $181.0 \mathrm{in}$ control with specifically saline irrigation (Table 5 ). The $[\mathrm{K}]$ remained inconsistent with EC of irrigation water. Robbins (1984) concluded that higher $[\mathrm{K}]$ were held in soil while $\mathrm{Na}$ leached down that reduced SAR and ESP. Potassium competes with other cations such as $\mathrm{Ca}$ and $\mathrm{Mg}$ for retention on soil exchange sites and high $\mathrm{K}$ levels may lead to increased leaching of $\mathrm{Na}$ and associated anions such as $\mathrm{SO}_{4}$ and $\mathrm{Cl}$ (Morton et al., 2004).

The $[\mathrm{Ca}]$ and $[\mathrm{Mg}]$ significantly $(\mathrm{P}<0.05)$ increased with saline irrigation but were not affected with $\mathrm{K}$ or $\mathrm{P}$ treatments (Table 5-6). A slight increase in [Ca] was observed with $\mathrm{K}$ under both irrigations. Hence, Ca:K ratio slightly decreased with $\mathrm{K}$ and increased with $\mathrm{P}$. The leaching of $\mathrm{Mg}$ increased with $\mathrm{P}$ and $\mathrm{K}$ treatments alone or in combination and/or with saline irrigation. The $\mathrm{Ca}$ and $\mathrm{Mg}$ in leachates suggested that $\mathrm{K}$ application resulted in more $\mathrm{Ca}$ than $\mathrm{Mg}$ leaching (Morton et al., 2004). The [Na], [Ca] and [Mg] were responsible for the variations in SAR of the leachates. Also, saline water in a saline-sodic soil increased soil SAR as a result of leaching of $\mathrm{Na}$ from surface layers (Akhtar et al., 2003).
As compared to other ions, $[\mathrm{P}]$ seemed to be lower in the leachates ranging from 0.11 to $0.35 \mathrm{mg} \mathrm{kg}^{-1}$. The total $\mathrm{P}$ values of leachates, however, increased significantly with application of $\mathrm{P}$ alone or in combination with $\mathrm{K}$. When averaged across $\mathrm{K}$ and irrigation waters, $\mathrm{P}$ leached was 0.13 and $0.33 \mathrm{mg} \mathrm{kg}^{-1}$ at $\mathrm{P}_{0}$ and $\mathrm{P}_{1}$, respectively (Table 5-6). The EC of irrigation water affected [P], Ca:P, Cl:P and $\mathrm{SO}_{4}: \mathrm{P}$ ratios. These ratios in leachates increased with $\mathrm{K}$ and decreased with $\mathrm{P}$ under both irrigation water. The overall low levels of $\mathrm{P}$ in leachates suggested the ion mobility of P in soil-leachate system. Curtin et al. (1992) reported that $[\mathrm{P}]$ leachate were usually lower $(0.1 \mathrm{mg}$ $\mathrm{L}^{-1}$ ) when EC was higher. With increased sodicity, the water extractability of $\mathrm{P}$ increased substantially. This trend was not observed in this study as the values of SAR and P leached showed no consistency.

The $\left[\mathrm{SO}_{4}\right]$ and $[\mathrm{Cl}]$ significantly increased in all the leachates with the addition of $150 \mathrm{~kg} \mathrm{~K}_{2} \mathrm{O} \mathrm{ha}^{-1}$ producing higher values with saline irrigation. The $\mathrm{P}$ addition significantly decreased $\left[\mathrm{SO}_{4}\right]$. The significant interactive effect of $\mathrm{P} \times \mathrm{K}$ on $\mathrm{Cl}: \mathrm{P}$ and $\mathrm{SO}_{4}: \mathrm{P}$ ratios described the importance of $\mathrm{K}_{2} \mathrm{SO}_{4}$ and $\left(\mathrm{NH}_{4}\right)_{2} \mathrm{HPO}_{4}$ in saline-sodic soil (Table 6-8). Timpson et al. (1984) reported the dominance of $\mathrm{SO}_{4}$ over $\mathrm{Cl}$ in the ground water which may be associated with gypsiferous parent material.

According to Suh et al. (2003), $\mathrm{Na}$ and $\mathrm{Cl}$ were weakly adsorbed on saline soil and $\mathrm{Ca}, \mathrm{K}$ and $\mathrm{Mg}$ were easily leached down. Morton et al. (2004) also found the increasing rates of $\mathrm{Cl}$ leaching with application of $\mathrm{K}$ as compared to control.

The addition of $150 \mathrm{~kg} \mathrm{~K}_{2} \mathrm{O} \mathrm{ha}^{-1}$ as $\mathrm{K}_{2} \mathrm{SO}_{4}$ alone or in combination with $120 \mathrm{~kg} \mathrm{P}_{2} \mathrm{O}_{5} \mathrm{ha}_{-1}$ as DAP increased $\left[\mathrm{SO}_{4}\right]$ in the leachates. It was noticed that $\left[\mathrm{SO}_{4}\right]$ was increased with saline water compared to non-saline water.

The increased ratios of $\mathrm{Cl}: \mathrm{SO}_{4}$ with DAP and decreased with $\mathrm{K}_{2} \mathrm{SO}_{4}$ in leachate from the soil could play a vital role in the chemistry of soil. 
Table 8. Ionic ratios in saturated extracts of post-harvest soil as affected by the levels of $\mathrm{P}$ and $\mathrm{K}$ under saline irrigation

\begin{tabular}{|c|c|c|c|c|c|c|c|c|}
\hline $\mathrm{P}_{2} \mathrm{O}_{5}$ & $\mathrm{~K}_{2} \mathrm{O}$ & $\mathrm{Na}: \mathrm{K}$ & $\mathrm{Na}: \mathrm{Ca}$ & $\mathrm{Ca}: \mathrm{K}$ & $\mathrm{Ca}: \mathrm{P}$ & $\mathrm{Cl}: \mathrm{P}$ & $\mathrm{SO}_{4}: \mathrm{P}$ & $\mathrm{SO}_{4}: \mathrm{Cl}$ \\
\hline \multicolumn{9}{|c|}{ 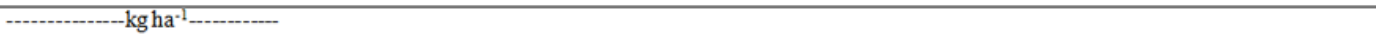 } \\
\hline \multicolumn{9}{|c|}{ Non-saline irrigation water } \\
\hline \multirow[t]{2}{*}{0} & 0 & 83.7 & 3.55 & 23.0 & 13.9 & 13.8 & 35.2 & 2.6 \\
\hline & 150 & 40.3 & 2.85 & 15.1 & 14.2 & 9.5 & 45.1 & 4.8 \\
\hline \multirow[t]{2}{*}{120} & 0 & 96.6 & 3.85 & 25.1 & 7.9 & 8.3 & 20.4 & 2.6 \\
\hline & 150 & 45.5 & 3.93 & 11.7 & 7.0 & 7.6 & 27.3 & 3.7 \\
\hline \multicolumn{9}{|c|}{ Saline irrigation water } \\
\hline \multirow[t]{2}{*}{0} & 0 & 64.5 & 3.49 & 18.5 & 15.4 & 33.7 & 33.5 & 1.0 \\
\hline & 150 & 42.5 & 3.53 & 12.2 & 12.5 & 29.1 & 37.7 & 1.3 \\
\hline \multirow[t]{2}{*}{120} & 0 & 69.9 & 3.35 & 21.2 & 11.8 & 23.3 & 20.0 & 0.9 \\
\hline & 150 & 38.2 & 2.72 & 14.1 & 11.4 & 24.9 & 27.5 & 1.1 \\
\hline \multicolumn{2}{|c|}{$\operatorname{LSD}(0.05)$} & 3.45 & 0.11 & 0.45 & 0.23 & 2.44 & 1.56 & 0.02 \\
\hline
\end{tabular}

The $\left[\mathrm{CO}_{3}\right]$ and $\left[\mathrm{HCO}_{3}\right]$, in contrast to other cations and anions, were not affected with EC of irrigation waters (Table 6-8). The addition of $120 \mathrm{~kg} \mathrm{P}_{2} \mathrm{O}_{5} \mathrm{ha}^{-1}$ and $150 \mathrm{~kg} \mathrm{~K} \mathrm{O}_{2} \mathrm{ha}^{-1}$ increased $\left[\mathrm{CO}_{3}\right]$ and $\left[\mathrm{HCO}_{3}\right]$ in nearly all the leachates irrespective of the quality of irrigation water. The higher $\mathrm{pH}$ of soils might be associated with higher $\mathrm{CO}_{3}$ and $\mathrm{HCO}_{3}$.

Excessive irrigation with saline and non-saline water increased the leaching of salts from the soil profile. Qadir et al. (2000) reported that soils with excessive salt concentrations could be ameliorated by continuous ponding. Cropping in conjunction with leaching was found to be sustainable way to ameliorate saline soils. Viegas et al. (2001) reported that increasing levels of $\mathrm{Na}$ and $\mathrm{Cl}$ were toxic to plants that might cause disturbances in metabolic and physiological functions leading to poor crop production. To minimize adverse effects, $\mathrm{Na}$ and $\mathrm{Cl}$ could be leached down from the root zone through excessive irrigation (Qadir et al., 2006). Continuous cropping with sodic water and inorganic fertilizer use slightly decreased the soil $\mathrm{pHe}$ and SAR (Yaduvanshi and Swarup, 2007). These results supported the findings of the present study suggesting that $\mathrm{K}$ and $\mathrm{P}$ fertilizers must be used to sustain the productivity of wheat in salt affected areas having saline ground water for irrigation.

\subsection{Chemical composition of post-harvest soil}

Results showed that the saline irrigation significantly increased $\mathrm{EC}_{\mathrm{e}}$, [Na], [K], [Ca], [Mg], [Cl], [CO $]$, SAR and ratios of $\mathrm{Ca}: \mathrm{P}, \mathrm{Cl}: \mathrm{P}$ and $\mathrm{SO}_{4}: \mathrm{Cl}$ in saturated extracts of post-harvest soils, while AB-DTPA extractable [P] and $\left[\mathrm{SO}_{4}\right], \mathrm{Na}: \mathrm{K}, \mathrm{Na}: \mathrm{Ca}, \mathrm{Ca}: \mathrm{K}$, and $\mathrm{SO}_{4}: \mathrm{P}$ ratios in saturated extracts were not affected (Table 7-8). The effect of $\mathrm{P}$ treatment was significant on AB-DTPA extractable $[\mathrm{P}]$ and ratios of $\mathrm{Ca}: \mathrm{P}, \mathrm{Cl}: \mathrm{P}, \mathrm{SO}_{4}: \mathrm{P}$ and $\mathrm{SO}_{4}: \mathrm{Cl}$ in soils while other parameters were not affected by $\mathrm{P}$ addition. The interaction of $\mathrm{EC}_{\mathrm{iw}} \times \mathrm{P}$ had significant effect on AB-DTPA extractable [P], [Ca], $\left[\mathrm{CO}_{3}\right], \mathrm{SAR}, \mathrm{Na}: \mathrm{Ca}$ and $\mathrm{Ca}: \mathrm{P}$ ratios. The application of $\mathrm{K}$ significantly affected [Na], [K], [SO $\mathrm{SO}_{4}$, SAR and ratios of $\mathrm{Na}: \mathrm{K}, \mathrm{Ca}: \mathrm{K}$, $\mathrm{SO}_{4}: \mathrm{P}$ and $\mathrm{SO}_{4}: \mathrm{Cl}$ while other parameters were not affected. The interaction of $\mathrm{EC}_{\mathrm{iw}} \times \mathrm{K}$ could not affect all the parameters except [Na], $\left[\mathrm{CO}_{3}\right], \mathrm{SAR}$ and $\mathrm{SO}_{4}: \mathrm{Cl}$ ratio. All the parameters were not affected by $\mathrm{P} x \mathrm{~K}$ interactions except $\left[\mathrm{CO}_{3}\right]$ and $\mathrm{SO}_{4}: \mathrm{Cl}$ ratio. The interactions 
of $\mathrm{EC}_{\mathrm{iw}} \times \mathrm{P} \times \mathrm{K}$ significantly affected $[\mathrm{Mg}]$ and SAR in soil saturation extracts while all other parameters were not affected (Tables 7-8).

The addition of $\mathrm{P}$ and $\mathrm{K}$ fertilizers under both saline and non-saline irrigation significantly influenced the salts and nutrients dynamics in the soils. A significant decrease in the values of $\mathrm{EC}_{\mathrm{e}}, \mathrm{Na}, \mathrm{Ca}, \mathrm{K}, \mathrm{SAR}$, and increase in $\mathrm{pH}$ was observed (Table 7) as compared to initial values. The overall higher values of $\mathrm{pH}$ in the post-harvest soil might attribute the release of $\mathrm{HCO}_{3}$ and $\mathrm{CO}_{3}$ in the soil. The values of post harvest soil $\mathrm{EC}_{\mathrm{e}}$ were significantly $(\mathrm{P}<0.001)$ decreased by both saline and non-saline water. The significant decrease in $\mathrm{EC}_{\mathrm{e}}$ values were obviously related to leaching of salts as evident from the decreases in concentrations of cations and anions. The values of post-harvest soils irrigated increased with saline water compared to those irrigated with non-saline waters (Tables 7-8). The decrease in EC of saline soils in pots irrigated with non-saline waters might be associated with consecutive irrigations and seasonal rainfalls. The $[\mathrm{K}]$ in soil solution significantly $(\mathrm{P}<0.001)$ increased with the addition of $\mathrm{K}$ fertilizers (Tables 7-8). Addition of $150 \mathrm{~kg} \mathrm{~K}_{2} \mathrm{O} \mathrm{ha}^{-1}$ increased [K] in soil to 0.28 and 0.26 at $\mathrm{P}_{0}$ and 0.27 and $0.35 \mathrm{mmol}(+) \mathrm{L}^{-1}$ at $\mathrm{P}_{1}$ with nonsaline and saline irrigation, respectively. Increases in the soluble $[\mathrm{K}]$ in soil promoted $\mathrm{K}$ uptake which could interfere the uptake of other cations ( $\mathrm{Na}, \mathrm{Ca}$ and $\mathrm{Mg}$ ). These phenomena can reduce adverse effects of the salinity (Abd El-Hadi et al., 2001).

The saline irrigation water had significant $(\mathrm{P}<0.001)$ effect on the $[\mathrm{Na}]$ which increased with saline irrigation and decreased with $\mathrm{K}$ treatment (Tables 7-8). Reduced $[\mathrm{Na}]$ might be due to leaching due to irrigation, irrespective of saline or non-saline water. The effect of the addition of $150 \mathrm{~kg} \mathrm{~K}_{2} \mathrm{O} \mathrm{ha}^{-1}$ alone $(\mathrm{P}<0.001)$ or in combination with $120 \mathrm{~kg} \mathrm{P}_{2} \mathrm{O}_{5} \mathrm{ha}^{-1}$ was significantly decreased $[\mathrm{Na}]$ in soil solution (Tables 7-8). Correspondingly, the ratios of $\mathrm{Na}: \mathrm{K}, \mathrm{Ca}: \mathrm{K}$ and SAR of soil solution also decreased significantly $(\mathrm{P}<0.001)$ with $\mathrm{K}$ treatments. Despite the plant's showed affinity for $\mathrm{K}$ over $\mathrm{Na}$, the $\mathrm{K}$ uptake by plants is related to the $\mathrm{Na}: \mathrm{K}$ ratio in the soil.

The values of SAR of the soil saturation extracts were decreased and the decrease in SAR might be associated with leaching down of $\mathrm{Na}$ with excess irrigation. Thus addition of $\mathrm{K}$ alone or in combination with $\mathrm{P}$ with excess saline or non-saline irrigation decreased Na producing as low as 5.21 and 5.26 SAR values. The soils with $\mathrm{SAR}>13$ are considered as sodic or saline-sodic soils (Richards, 1954). Initial higher values of SAR substantially decreased with irrigation and rainfall in pots. This suggested the successful reclamation of salt affected soils and improvements in soil nutrients could be achieved with the addition of $\mathrm{P}$ and $\mathrm{K}$ fertilizers.

The saline irrigation water had non-significant effect on AB-DTPA extractable [P] but increased significantly $(\mathrm{P}<0.001)$ with the addition of $\mathrm{P}$ alone or in combination with $\mathrm{K}$ treatments. However, application of $\mathrm{K}$ alone inconsistently affected [P] in the soils. Addition of $\mathrm{P}_{1}$ alone or in combination with $\mathrm{K}_{1}$ treatments increased $[\mathrm{P}]$ to $11 \mathrm{mg} \mathrm{kg}^{-1}$ soil which is considered sufficient for plant growth (Soultanpour and Schwab, 1977). The values ranged from 9.26 to $13.7 \mathrm{mg} \mathrm{kg}^{-1}$ when averaged across ECiw and $\mathrm{K}$ treatments (Table 7-8). The $[\mathrm{Ca}]$ and $\mathrm{Ca}: \mathrm{P}$ ratios were significantly decreased by the addition of combined $\mathrm{P}$ and $\mathrm{K}$ with nonsaline irrigation. A similar trend in $[\mathrm{Mg}]$ was observed. There was a slight increase in $[\mathrm{Ca}]$ and $[\mathrm{Mg}]$ with saline irrigation which may be associated with additions through saline irrigation to the soil solution.

Phosphorus solubility in saline soil with higher $\mathrm{Ca}$ activity is controlled by $\mathrm{P}$ sorption processes on the solid phase of Ca-minerals. The rate of $\mathrm{P}$ removal from solution due to sorption and/or precipitation was relatively slow and the initial calcium phosphate formed was thermodynamically unstable (Grattan and Grieve, 1992). Bauder and Brock (2001) reported that addi- 
tion of phospho-gypsum $\left(\mathrm{P}-\mathrm{CaSO}_{4}\right)$ to soil was needed to replace the $\mathrm{Na}$. Therefore, the application of $\mathrm{P}$ fertilizer is suggested to improve the $\mathrm{P}$ status of soils. In saline soils, [Ca] usually increase as the total salt concentrations increase. The higher values of $\mathrm{Ca}$ and $\mathrm{Mg}$ may be beneficial in terms of reclamation of sodic soils by lowering SAR values. Zaman et al. (2002) reported that $\mathrm{NaSO}_{4}$ was less toxic than $\mathrm{NaCl}$ for the growth of wheat provided $\mathrm{K}$ and $\mathrm{Ca}$ are available in the growth medium. Morton et al. (2004) reported that there was no effect of $\mathrm{K}$ on $[\mathrm{Ca}]$ and $[\mathrm{Mg}]$ despite leaching of both cations which could be attributed to their higher concentrations on the soil exchange sites. Therefore the availability of macronutrients in saline or saline-sodic soils is beneficial for the yield of crops. The excess of $\mathrm{Ca}$ in the medium causes retardation in the growth of shoot whereas in the saline-sodic medium when $\mathrm{Na}$ is more available, the abundance of $\mathrm{Ca}$ ion is required to check the toxic activities of $\mathrm{Na}$ ion (Zaman et al., 2005).

The $[\mathrm{Cl}]$ and $\mathrm{Cl}: \mathrm{P}$ ratio significantly $(\mathrm{P}<0.001)$ increased with saline irrigation, while $[\mathrm{Cl}]$ decreased slightly with $\mathrm{K}$ treatments. The $\left[\mathrm{SO}_{4}\right]$ and ratios of $\mathrm{SO}_{4}: \mathrm{P}$ and $\mathrm{SO}_{4}: \mathrm{Cl}$ increased with $\mathrm{K} 1$ treatments (Tables 7-8). The increased $\left[\mathrm{SO}_{4}\right]$ and its ratios might be due to addition of $\mathrm{K}$ as $\mathrm{K}_{2} \mathrm{SO}_{4}$ fertilizer. However, saline irrigation water did not produce much difference in $\mathrm{SO}_{4}$ levels. The overall low soil $[\mathrm{Cl}]$ might be due to leaching of $\mathrm{Cl}$ from the soil profile. The high $[\mathrm{Cl}]$ with saline irrigation produced higher $\mathrm{Cl}: \mathrm{SO}_{4}$ ratios than with non-saline irrigations, but the ratios decreased at $\mathrm{K} 1$. The inputs of $\mathrm{SO}_{4}$ as $\mathrm{K}_{2} \mathrm{SO}_{4}$ to soils tended to decrease $\mathrm{Cl}: \mathrm{SO}_{4}$ ratios.

The $\left[\mathrm{HCO}_{3}\right]$ was not affected by the application of $\mathrm{P}$ and $\mathrm{K}$ treatments as well as by the saline irrigation water. The $\left[\mathrm{CO}_{3}\right]$ were significantly $(\mathrm{P}<0.05)$ affected by all the treatments, with lowest values of 0.6 in control under non-saline treatment and $0.55 \mathrm{mmol} \mathrm{L}^{-1}$ in saline treatments with $\mathrm{P}_{2}$ and $\mathrm{K}_{2}$ (Tables 7-8). The behavior of soil to addition of treatments as $\mathrm{K}$ and $\mathrm{P}$ and their interactions with other ions may be variable due to the complex soil-water-plant system which is regulated by processes such as sorption, desorption, precipitation and complexation (Sposito, 1989). The chemical analysis of soil in the present study indicated the beneficial effect of $\mathrm{K}$ and $\mathrm{P}$ addition to soil in minimizing salt hazard and improvement in soil properties even under saline irrigation.

\section{Conclusions}

It is concluded that the application of $\mathrm{K}$ and $\mathrm{P}$ had significant effects on the dry matter yield. The growth of the plants was adversely affected by the saline irrigation. The grain and dry matter yield of wheat decreased with saline irrigation as compared to non-saline water. The $\mathrm{P}$ addition significantly affected shoot and root $[\mathrm{P}]$ and that of $[\mathrm{Na}],[\mathrm{K}]$ and $[\mathrm{Mg}]$ in shoot tissue while the K:Na ratio was non-significantly affected under both irrigation systems. The ECiw x P interaction had significant effect on $[\mathrm{Na}]$ and $\mathrm{K}: \mathrm{Na}$ ratio in root tissue while $[\mathrm{P}],[\mathrm{Na}],[\mathrm{K}],[\mathrm{Ca}],[\mathrm{Mg}]$ and $\mathrm{K}: \mathrm{Na}$ ratio were not affected in shoot tissue. The $\mathrm{K}$ addition significantly affected $[\mathrm{Na}],[\mathrm{K}]$ and $\mathrm{K}: \mathrm{Na}$ ratio in shoot. All the parameters were significantly affected by the addition of $\mathrm{K}$ in root. The Ca uptake by roots increased with saline irrigation. The increasing $\mathrm{P}_{2} \mathrm{O}_{5}$ level significantly increased $[\mathrm{P}]$ in shoot and root tissue under both irrigation waters. The addition of $\mathrm{P}$ increased $[\mathrm{P}]$ in both shoot and root tissue. The $\mathrm{Na}$ uptake by root and shoot tissues was depressed with the addition of $\mathrm{P}$ and $\mathrm{K}$ fertilizers. The higher $\mathrm{K}$ uptake increased K:Na ratio in both wheat tissues. The decrease $[\mathrm{Ca}]$ could be associated with $\mathrm{P}$ and $\mathrm{K}$ treatments. The values of EC, SAR and $[\mathrm{P}],[\mathrm{Na}],[\mathrm{Ca}]$, $[\mathrm{Mg}],[\mathrm{Cl}]$ and ratios of $\mathrm{Na}: \mathrm{K}, \mathrm{Ca}: \mathrm{P}, \mathrm{Cl}: \mathrm{P}$ and $\mathrm{SO}_{4}: \mathrm{P}$ in the soil leachates significantly increased with saline irrigation while $\mathrm{pH}$ values and $[\mathrm{K}],\left[\mathrm{SO}_{4}\right],\left[\mathrm{CO}_{3}\right]$ and 
$\left[\mathrm{HCO}_{3}\right]$ did not change with saline irrigation waters. Except other soil parameters, the addition of $\mathrm{P}$ had significant effect on soil $\mathrm{pH}, \mathrm{SAR},[\mathrm{P}],\left[\mathrm{SO}_{4}\right],\left[\mathrm{CO}_{3}\right]$ and $\left[\mathrm{HCO}_{3}\right]$ and $\mathrm{Ca}: \mathrm{P}, \mathrm{Cl}: \mathrm{P}$ and $\mathrm{SO}_{4}: \mathrm{P}$ ratios in leachates. Saline irrigation significantly increased $\mathrm{EC}_{\mathrm{e}},[\mathrm{Na}]$, $[\mathrm{K}],[\mathrm{Ca}],[\mathrm{Mg}],[\mathrm{Cl}],\left[\mathrm{CO}_{3}\right]$, SAR and ratios of $\mathrm{Ca}: \mathrm{P}$, $\mathrm{Cl}: \mathrm{P}$ and $\mathrm{SO}_{4}: \mathrm{Cl}$ in saturated extracts of post-harvest soils. This study could suggest that the addition of $\mathrm{P}$ and $\mathrm{K}$ under saline conditions may be beneficial to crop productivity and minimize the adverse effects of $\mathrm{Na}$ in plant growth.

\section{Acknowledgements}

The authors thankfully acknowledge the funding of Higher Education Commission (HEC) of Pakistan through the first author. The useful comments and suggestions made by the reviewers for the improvement of this manuscript are also highly appreciated.

\section{References}

Abd El-Hadi, A.H., Khader, M.S. El-Kholy, M.H., Zahran, F.A., Negm. A.Y. 2001. Phosphorus and potash effects. Soils, Water and Environ. Res. Inst., ARC, Egypt.

Akhtar, J., Mahmood, K., Malik, K.A., Ahmad, S., Murray, R. 2003. Amelioration of saline-sodic soil through cultivation of a salt-tolerant kallar grass Leptochloa fusca. Environ. Cons. 30, 168-174.

Ali, Y., Aslam, Z., Ashraf, M.Y., Tahir, G.R. 2004. Effect of salinity on chlorophyll concentration, leaf area, yield and yield components of rice genotypes grown under saline environments. Int. J. Environ. Sci. Technol. 1, 229-234.

Ali, C.K., Javed, M., Javaid, M.A. 1999. Growth promotion of wheat by potassium application in saline soils. J. Ind. Soc. Soil Sci. 47, 510-513.
Ashraf, M.Y., Sarwar, G. 2002. Salt tolerance potential in some members of Brassicaceae. Physiological studies on water relations and mineral contents. In: Prospects of saline agriculture. R. Ahmad and K. A. Malik (Eds.). Kluwer Academic Publishers, Netherlands. 237-245.

Bates, T., Lynch, J. 2000. Plant growth and phosphorus accumulation of wild type and two root hair mutants of Arabidopsis thaliana (Brassicaceae). Am. J. Bot. 87, 958-963.

Benton, J.Jr., Wolf, B., Mills, H.A. 1991: Plant analysis hand book. A Practical Sampling, Preparation, Analysis and Interpretation Guide. Micro-Macro Publishing Inc., USA.

Curtin, D., Selles, F., Steppuhn, H. 1992. Influence of salt concentration and sodicity on the solubility of phosphate in soils. Soil Sci. 153, 409-416.

Cruz, V., Cuartero, J., Bolarin, M.C., Romero, M. 1990. Evaluation of characters for ascertaining salt stress responses in Lycopersicon species. J. Am. Soc. Hort. Sci. 115, 1000-1003.

Flowers, T.J., Yeo, A.R. 1986. Ion relations of plants under drought and salinity. Aust. J. Plant Physiol. $13,75-91$.

Gee, G.W., and Bauder, J.W. 1986. Particle-size analysis. In: Klute A (ed), Method of Soil Analysis, Part 1, Agronomy series No. 9. Am. Soc. Agron. Soil Sci. Soc. Am. Inc Publ, Madison WI, USA pp 383-441.

Grattan, S.R., Grieve, C.M. 1993. Mineral element acquisition and growth response of plants grown in saline environments. In: A Handbook of Plant and Crop Stress. Pessarakly, M. (ed.). Marcel Dekker, Inc. New York. Ch. 9, 203-226.

Grieve, C.M., Fujiyama, H. 1987. The response of two rice cultivars to external $\mathrm{Na}$ :Ca ratio. Plant Soil. 103, 245-250. 
Gronwald, J.W., Suhayda, C.G., Tal, M., Shannon, M.C. 1990. Reduction in plasma membrane ATPase activity of tomato roots by salt stress. Plant Sci. 66, 145-153.

Gibson, T.S. 1988. Carbohydrate metabolism and phosphorus/salinity interactions in wheat (Triticum aestivum L.). Plant Soil. 111, 25-35.

Haider, Z.M, Hossain, Z.M 2013. Impact of salinity on livelihood strategies of farmers. J. Soil Sci. Plant Nutr. 13, 417-431.

Hussain, Z., Khattak, R.A., Irshad, M., Eneji, A.E. 2013. Ameliorative efffect of potassium sulphate on the growth and chemical composition of wheat (Triticum aestivum L.) in salt-affected soils. J. Soil Sci. Plant Nutr. 13, 401-415.

Iqbal, R.A. 2003. Growth Physiology of Spring Wheat under Saline Conditions. Asian J. Plant Sci. 2(17), 1156-1161.

Jarrell, W.M., Beverly, R.B.1981. The dilution effect in plant nutrition studies. Adv. Agron. 34, 197-224.

Kinraide, T. 1999. Interactions among $\mathrm{Ca}^{2+}, \mathrm{Na}^{+}$and $\mathrm{K}^{+}$in salinity toxicity: quantitative resolution of multiple toxic and ameliorative effects. J. Exp. Bot. 50, 1495-1505.

Lynch, J., Läuchli, A. 1985. Salt stress disturbs the calcium nutrition of barley (Hordium vulgare L.). New Phytol. 99, 345-354.

Maas, E.V., Grieve, C.M. 1987. Sodium-induced calcium deficiency in salt-stressed corn. Plant Cell Environ. 10, 559-564.

Mass, E.V. 1990. Crop salt tolerance. In: K. K. Tanji, ed. Agricultural Salinity Assessment and Management. American Society of Civil Engineering,

Manai, J., Kalai1, T., Gouia, H., Corpas, F.J. 2014. Exogenous nitric oxide (NO) ameliorates salinity-induced oxidative stress in tomato (Solanum lycopersicum) plants. J. Soil Sci. Plant Nutr. 14, 433-446.
McLean, E.0. 1982. Soil $\mathrm{pH}$ and lime requirement. In A.L. Page, R. H. Miller, and D. R Keeney (ed.) Methods of soil analysis, Part 2, 2nd ed. Agron. 9, 199-208.

Minhas, P.S. 1996. Saline water management for irrigation in India. Rev. Agric. Water Manage. 28, 273-288.

Muhammad, D., Khattak, R.A. 2009. Growth and nutrients concentrations of maize in pressmud treated saline-sodic soils. Soil Environ. 28, 145-155.

Munns, R., Greenway, H., Kirst, G.O. 1983. Halotolerant. In: Physiological Plant Ecology III. Response to the chemical and biological environment. Lang, O. L., P. S. Nobel, C. B. Osmand, and H. Ziegler (Eds.). Encycl. Plant Physiol. New Ser. 12, 59-135.

Morton, J.D., Roach, C.G., Tong, M.J., Roberts, A.H.C. 2004. Potassium in soil and pasture and leaching of cations on an allophanic soil in New Zealand. New Zealand. J. Agric. Res. 47, 147154.

Nelson, D.W., Sommers, L.E. 1982. Total carbon, organic carbon and organic matter. In A.L. Page, R.H. Miller, and D.R. Keeney (ed.) Methods of soil analysis, Part 2, 2nd ed. Agron. 9, 574-577

Qadir, M., Ghafoor, A., Murtaza, G. 2000. Amelioration strategies for saline soils: a review. Land Degrad. Dev. 11, 501-521.

Qadir, M., Noble, A.D., Schubert, S., Thomas, R.J., Arslan, A. 2006. Sodicity induced land degradation and its sustainable management. Land Degrad. Dev. 17, 661-676.

Rameeh, V. 2012. Ions uptake, yield and yield attributes of rapeseed exposed to salinity stress. J. Soil Sci. Plant Nutr. 12, 851- 861.

Rhoades, J.D. 1987. Use of saline water irrigation. Water Quality Bull. 12, 14-22. 
Richards, L.A. 1954. Diagnosis and improvement of saline and alkali soils; Agriculture Handbook 60. USDA, US Printing Office, Washington D.C.

Robbins, C.W. 1984. Sodium adsorption ratio-exchangeable sodium percentage relationships in a high potassium saline-sodic soil. Irrig. Sci. 5, 173-179.

Sharpley, A.N., Meisinger, J.J. Power, J.F., Suarez, D.L. 1992. Root extraction of nutrients associated with long-term soil management. In: Advances in Soil Science. B. Stewart (ed.). Springer-Verlag. 151-217.

Shibli, R.A., Sawwan, J., Swaidat, I., Tahat, M. 2001. Increased phosphorus mitigates the adverse effects of salinity in tissue culture. Commun. Soil Sci. Plant Anal. 32(3-4), 429-440.

Shirazi, M.U., ashraf, M.Y., Khan, M.A., Naqvi, M.H. 2005. Potassium induced salinity tolerance in wheat (Triticum aestivum L.). Int. J. Environ. Sci. Technol. 2, 233-236.

Soultanpour, P.N., Schwab, A.P. 1977. A new soil test for simultaneous extraction of macro- and micronutrients in alkaline soils. Commun. Soil Sci. Plant Anal. 8, 195-207.

Sposito, G. 1989. The Chemistry of Soils. Oxford University Press Inc. New York. pp. 1-277.

Suh, J.Y., Brown, P.L., Birch, G.F. 2003. Geochemical factors affecting leachate composition derived from soils in reclaimed lands using laboratory fresh and saline water column experiments. Marine Freshwater Res. 54, 885-893.
Tanji, K.K. 1990. Agricultural salinity assessment and management. Am. Soc. Civil Engin. pp 615.

Thomas, G.W. 1996. Soil pH and soil acidity. p. 475490. In: Methods of Soil Analysis. D.L. Sparks (ed.). Part 3. American Society of Agronomy, WI, USA.

Viegas, R.A., da Silveira, J.G., de Lima Junior, A.R., Queiroz, J.E., Fausto, M.J.M. 2001. Effects of $\mathrm{NaCl}$-salinity on growth and inorganic solute accumulation in young cashew plants. R. Bras. Eng. Agric. Ambiental, Camina Grande. 5, 216-222.

Yoshida, S., Foano, D.A., Cock, J.H., Gomez, K.A. 1976. A laboratory manual for physiological studies of Rice, Ed. 3. pp. 13-8. International Rice Research Institute Philippines.

Yaduvanshi, N.P.S., Swarup, A. 2007. Effect of continuous use of sodic irrigation water with and without gypsum, farmyard manure, pressmud and fertilizer on soil properties and yields of rice and wheat in a long term experiment. Nutr. Cyc. Agroecosys. 73, 111-118.

Zaman, B., Ali, A., Salim, M., Hussain, K. 2002. Growth of wheat as affected by sodium chloride and sodium sulphate salinity. Pak. J. Biol. Sci. 5, 1313-1315

Zaman, B., Niazi, B.H., Athar, M., Ahmad, M. 2005. Response of wheat plants to sodium and calcium ion interactions under saline environment. Int. J. Environ. Sci. Technol. 2, 7-12.

Zhukovskaya, N.V. 1973. Absorption and accumulation of phosphate by plants under conditions of soil salinization. Soviet Plant Physiol. 20, 55-61. 